\title{
The Impact of Early Adoption of IFRS on the Quality of Accounting Information
}

\author{
Faouzi Jilani*, Basma Ben Néfissa \\ Faculty of Economic Sciences and Management of Tunis, University of Tunis El Manar, Tunisia
}

\begin{abstract}
After the various financial scandals, the debate concerning accounting information has been renewed in earnest. Consequently, we have decided to study the quality of accounting information. Indeed the aim of this article, which spans from the period of 2002 to 2006, is to study the impact of early adoption of IFRS (International Financial Reporting Standards) on the quality of accounting information. After reviewing the literature, we chose to study the following aspects:earnings managment and timely loss recognition. This study deals with as ample of the CAC (Cotation Assistée en Continu: Scoring Assisted Continuous) 40 companies. Panel number one is made up of companies that foresaw the adoption of IFRS. Panel number two consist of companies that waited for the legal date for the adoption of IFRS. After empirical tests, we noticed that for panel number one, the quality of accounting information has improved; while in panel number two, we noticed an increase in earnings managment. In conclusion, not foreseeing the adoption of IFRS hampers the companies and increases earning management.
\end{abstract}

Keywords: IFRS; Accounting information; Earnings management; Timely recognition of loss

\section{INTRODUCTION}

The various financial scandals that mainly affected Europe and the United States have had considerable consequences on the economic sphere. These events have led researchers, practitioners and to a greater extent, the general public to suspect the real quality of accounting information. To this day, many questions remain unanswered. In such a context, the privileged users of accounting information have therefore questioned the quality of the accounting output disclosed through the financial statements. Disclosed accounting information: Does this information accurately reflects the economic reality in the true sense of the term, or is it built to meet investors' expectations as much as possible? Indeed, many researchers such as Kim and Zhang Cohen et al. have shown that fearing eviction, some executives take advantage of their discretionary space to bring the company's results to the threshold desired by investors by hiding bad news [1]. Infact, noting a very large heterogeneity in relationship to analysing the impact of the adoption of IFRS on the quality of accounting information motivated us to conduct our research on the association between the early adoption of IFRS and the quality of accounting information. The present study is original in the sense that it focuses on the impact of the early and non-mandatory adoption of IFRS on the quality of accounting information.
The interest of our research is therefore to prove that the fact that some companies anticipated IFRS before 2005 gave them an advantage overcompanies that waited for the regulatory date. The usefulness of our research work therefore lies in the fact that our subject is related to a topical issue, in this case, the focus on the determinants of the quality of accounting information, more particularly on the primacy of IFRS.

The problem of our research is therefore as follows: does the early adoption of IFRS guarantee an increase in the quality of accounting information? We will therefore respond to our problem by testing our different hypotheses on French companies belonging to the CAC 40 index. Indeed, the choice of our sample was motivated by the fact that the CAC 40 companies are French companies that apply standards following an Anglo-Saxon orientation in a French environment.

Based on a sample of 36 companies in the CAC 40 index monitored between 2002 and 2006, we show that companies that have voluntarily adopted IFRS have better quality accounting information than companies that have waited for the mandatory date, based on the attributes of earnings managment and timely recognition of losses.

After analysis we found that for our panel A, which is composed of companies that have early adopted IFRS, these companies present

${ }^{*}$ Correspondence to: Faouzi Jilani, Faculty of Economic Sciences and Management of Tunis, University of Tunis El Manar, Tunisia, Tel: +21650990051 ; E-mail: bennefissabasma@yahoo.fr

Received: January 15, 2019; Accepted: February 01, 2019; Published: February 08, 2019

Citation: Jilani F, Néfissa BB (2019) The Impact of Early Adoption of IFRS on the Quality of Accounting Information. Int J Account Res 7:195. doi: 10.35248/2472-114X.19.7.195

Copyright: ( 2019 Jilani F, et al. This is an open-access article distributed under the terms of the Creative Commons Attribution License, which permits unrestricted use, distribution, and reproduction in any medium, provided the original author and source are credited. 
to the privileged users of accounting information information that accurately reflects the economic reality, thus showing decrease in earnings management. This same information allows users to better anticipate probable losses. Thus, we have proven through our research that the early adoption of IFRS has granted significant benefits to these companies

Our article will therefore be composed of 4 parts: the first part presents the context of the research, the second part reviews the literature on the concepts of results management and the recognition of loss in a timely manner. The third part describes the methodology used. The fourth part will focus on the empirical analysis of the results and finally the conclusion.

\section{RESEARCH CONTEXT}

Following the various financial scandals that have shaken the economic sphere, the need to impose a common international accounting language has become an obligation from which no company can derogate. Thus, in order to overcome this lack of transparency, one of the means considered effective was the implementation of a common accounting language. Since the application of IFRS, the international accounting standards developed by the IASB (International Accounting Standards Board) allow economic entities to use the same language regardless of the geographical area they occupy, and the adoption of these standards, which many consider to be of "high quality", will contribute to meeting investors' information needs. As any change in the implementation of standards has been gradual, the standard-setter has sought to harmonize accounting practices in the first place. In accordance with Colasse, harmonization is defined as "a mitigated form of standardization, a certain convergence of accounting practices is aspired to, and secondly, it has standardized accounting practices" [2]. According to Hoarau, standardization is a "set of common rules whose dual purpose is to standardize and rationalize the presentation of accounting information likely to satisfy the presumed needs of users" [3].

Thus, in a context where the primacy of accounting information quality prevails, our research focuses on the impact of the early adoption of IFRS on the quality of accounting information. As Gaio pointed out, since the concept of quality is a multidimensional concept, our research will focus on the relationships between early adoption of IFRS and earnings management, as well as the relationship between recognition of loss in a timely manner and early adoption of IFRS.

\section{LITERATURE REVIEW}

\section{The concept of quality, a multidimensional concept}

Through a review of the literature, we note that research on the quality of accounting information is extensive and occupies a prominent place in the accounting sphere. Whereas previously accounting was a means for the accountant to justify himself to the contributors of capital in accordance with agency theory, nowadays with globalisation, the generalised growth of companies as well as the intensification of trade the "out put" of accounting has become a strategic tool in decision-making for the investor. In addition, the recent financial scandals that have "ravaged" both the United States and Europe have prompted public opinion, and in particular, practitioners to question the real quality of accounting information. Wouldn't the disclosure of real quality accounting information have prevented a financial crisis from occurring?
According to Gaio, the concept of quality is a multidimensional concept. As a result, the different authors have approached it in a different way. We can cite Ewert and Wagenholf who defined relevance, comparability and finally the absence of earnings management as the attributes of quality information. Assuming that the notion of quality can be approached from several angles, we will focus on a few attributes of quality.

First, we will study the practice of earnings management as defined by Stolowy and Breton as "exploiting the discretion left to managers in terms of accounting alternatives in order to modify investors' perceptions". Indeed, quality accounting information is the one that minimizes the practice of earnings management. Secondly, we will try to deal with the subject of the recognition of loss in a timely manner. Accounting information is of high quality when it makes it possible to anticipate quickly the beginnings of a future crisis. According to Basu, "a high degree of conservatism will allow the entity to recognize the loss in a timely manner, and the company will then be able to take the necessary measures to avoid this type of situation" [4].

\section{Effects of IFRS on earnings management}

Following the adoption of IFRS by many countries, a large number of researchers have carried out work to verify whether IFRS standards considered by a large majority to be "high quality" standards have a negative impact on earnings management.So, we will therefore show in the following section how the accounting literature on this topic is enriched by the diversity of its results.

In the French context, Cormier and Martinez have stated that for companies that want to go public, the adoption of IFRS leads to an expansion of the manager's field of action. These results were confirmed by Stowly and Jeanjean.

In another context, Capkun et al. chose to study the transition from local to international standards and concluded that the return on assets had increased [5]. 3 years later, these researchers confirmed the hypothesis that the early adoption of IFRS had led to a decrease in earnings management.

In the Chinese context Cangand et al. Stated that "the adoption of IFRS has contributed to the creation of an environment conducive to the development of creative accounting that is indirectly accepted by financial analysts, resulting in an increase in earnings management that has been noted".

In the Italian context, Paglietti and Callao have argued that "the adoption of IFRS has intensified the practice of earnings management". Indeed, these researchers concluded that the mere adoption of IFRS is not enough to affirm that the accounts are of high quality. Other determinants to be taken into consideration including governance mechanisms for judging the quality of accounting information.

In the Pakistani context, Khan and Baig conducted empirical research testing the impact of IFRS on an important attribute of accounting information, namely earnings management, on a sample of 100 companies listed on the Pakistani market followed for 3 periods: from 2002 to 2004, from 2005 to 2008 and finally from 2008 to 2011. At the end of their research, Khan and Baig concluded that earnings management had increased, following the transition to IFRS.These researchers justified this result by the fact that Pakistan is a country that has just recently joined IFRS since IFRS are standards that require both material preparation (implementation costs) and intangible preparation (staff must 
have the necessary skills to ensure proper application of IFRS) and adaptation time is necessary.

In the international context, Ahmed et al. conducted a study of 15 European countries that have adopted IFRS. After analysis, these researchers concluded that there was an increase in earnings management following the adoption of IFRS. Ahmed et al. justified their results by the fact that IFRS offers some flexibility to managers who use it in order to bring the company's results to the desired level [6].

Finally, in the Egyptian context, Ebaid focused in particular on the impact of the adoption of IFRS on the quality of accounting information, referring to a sample of 74 listed Egyptian companies analysed over two periods: 2000-2006 and 2007-2009. After analysis, this researcher noted that following the transition to IFRS, the quality of information had not improved. It should be noted that this research is relevant in the sense that it provides evidence that the significant benefits of IFRS are not consistently observed in all countries. In Egypt, for example, a code law country, the environmental specificities of this country, which area failing institutional framework and an environment that does not take into account the interests of privileged users of accounting information, have led to a decline in the quality of accounting information as a result of the transition to IFRS.

Thus, having presented the theoretical basis concerning the relationship between the early adoption of IFRS and earnings management and noting a great heterogeneity in the results, we haved formulated our first research hypothesis that underlies the beneficial effect of IFRS on the quality of accounting information.

H1: Early adoption of IFRS results in a decrease in earnings management.

\section{Effect of early adoption of IFRS on the recognition of loss in a timely manner}

Most studies have pointed out the beneficial effect of IFRS on accounting output. Indeed, according to Li, adopting IFRS reduces the information asymmetry that will result in more efficient investments. Ball et al. have stated that "the increased transparency of IFRS and the timely recognition of losses leads on the one hand to effective contractual clauses between the company and its various stakeholders and on the other hand to a fairly significant reduction in so-called agency costs" [7].

In another context, Ahmed et al. and André et al. concluded that the application of IFRS has led to a decrease in conservatism $[6,8]$.

Piot, Dumontier and Janin conducted a study on the effects of early adoption of IFRS on the recognition of loss in a timely manner. To carry out their studies, these authors chose a sample composed of 5464 companies from twenty-two EU Member States... At the end of their studies, these authors noted that the consideration of bad news had decreased while the consideration of good news had increased.

In the Turkish context, Ozkan and Durak studied the impact of IFRS on accounting conservatism. In order to carry out their studies, these authors used a sample of listed economic entities, the study period covered the period from 1992 to 2008, and concluded that there was a positive relationship between the adoption of IFRS and accounting conservatism.

Finally, in the Prague context, Masca and Neag noted an increase in accounting conservatism following the transition to IFRS for large economic entities [9].

Thus we put forward the following hypothesis as a second hypothesis

H2: The early adoption of IFRS makes it easier to predict losses.

\section{METHODOLOGY}

This section will present in a precise and concise manner the methodology followed. First we will present the sample on which our research is based. In a second step, we will present the variables that make up our models. Finally, we will focus on the various measures for earnings management and recognizing loss in a timely manner

\section{Sample}

In order to measure the impact of the early adoption of IFRS on the quality of accounting information, we have chosen to refer to French companies in the CAC 40 index (We referred to 36 companies rather than 40 , because of the unavailability of data from 4 companies).

We chose the period from 2002 to 2006 as the study period, because the voluntary adoption of IFRS began in 2004. For comparative purposes we wanted to conduct a study over two years before the voluntary adoption of IFRS and two years after the voluntary adoption of IFRS. We deliberately excluded 2004 from our research because it was a year of transition and could therefore bias our results.

It should be noted that we collected the data by referring to the financial statements, the reference documents and the annual reports, which were available on the websites of each of the companies.

\section{Variable description and measurements}

In order to test our assumptions, we have chosen, through a careful review of the accounting literature, the variables relevant to assessing earnings management and also those useful to measuring accounting conservatism (Tables 1 and 2).

\section{Measuring the earnings management}

The methodology used aims to measure two phenomena: eanings management and the recognition of loss in a timely manner for both categories of companies: companies that have voluntarily adopted IFRS (panel A) and companies that have waited for the mandatory adoption of IFRS (panel B).

The purpose of earnings management is to achieve a performance that follows a continuous trend. Indeed, to measure eanings management, particularly the smoothing of results, we refer to the research conducted by Barth et al. in the German context.

Indeed, we have chosen to refer to the approach followed by Barth et al. to measure earnings management firstly, because earnings management is measured in a context of voluntary transition to IFRS. Secondly, the model used by these researchers to measure earnings management seems relevant to us because it explains this phenomenon by determinants specific to the company such as the size of the company, the level of growth, the change in equity, the level of debt, financial autonomy, and more particular external determinants such as: listing on an American market and 
Table 1: Variables measuring earnings management.

\begin{tabular}{|c|c|c|c|}
\hline Type of variable & MeasuredEffect & Acronyme & Measure \\
\hline Independent & The size & SIZE & Natural logarithm of the market value of Equityat the end of the year $t$ \\
\hline Independent & The growth & GROWTH & Percentage change in turnover \\
\hline Independent & Changes in shareholders' equity & EISSUE & $\begin{array}{l}\text { Dichotomous variable whichisequal to } 1 \text { if the company has } \\
\text { increasedits capital } 0 \text { otherwise }\end{array}$ \\
\hline Independent & Asset Rotation & TURN & Ratio of total turnover to total assets \\
\hline Independent & Operating cash-flow & $\mathrm{CF}$ & Ratio of cash flowto total assets \\
\hline Independent & Audit & AUD & $\begin{array}{l}\text { Dichotomous variable which is } 1 \text { if the company is audited by a BIG } \\
\text { FOUR } 0 \text { otherwise }\end{array}$ \\
\hline Independent & $\begin{array}{l}\text { Number of stock exchanges on which a } \\
\text { company'sshares are listed }\end{array}$ & NUMEX & The number of stock marketswhere the company is listed \\
\hline Independent & Financial autonomy & LEV & Total liabilities over total shareholders' equity at the end of the year $t$ \\
\hline Independent & Executive's share in the capital & CLOSE & Percentage of shares held by the manager in the company \\
\hline Independent & Quotation on the American market & CUSA & $\begin{array}{l}\text { Dichotomous variable that is worth } 1 \text { if the company is present on the } \\
\text { American stock market }\end{array}$ \\
\hline Independent & $\begin{array}{l}\text { Changes in shareholders' equity and } \\
\text { liabilities }\end{array}$ & DISSUE & Percentage of the annual change in share holders' equity \\
\hline Independent & Listing on an American market & XLIST & $\begin{array}{l}\text { Binary variable that takes the value } 1 \text { if the company is listed on an } \\
\text { American market, } 0 \text { if not }\end{array}$ \\
\hline
\end{tabular}

Table 2: Variables measuring timely loss recognition.

\begin{tabular}{|c|c|c|c|}
\hline Type of variable & Measured Effect & Acronyme & Measure \\
\hline Dependent & Earnings per share & $\mathrm{NI}_{\text {it }}$ & Net income/common shares \\
\hline Dependent & Share price per share & $P_{t-1}$ & Share price on the closing date \\
\hline
\end{tabular}

the number of stock markets in which the company is present. In addition, we wanted to refer to the German context because it was in Germany that the first European companies adopted IFRS early.

$\Delta N I_{i t}$ ou $\Delta C F_{i t}=\alpha_{0}+\alpha_{1} S_{\text {SIZE }}+\alpha_{2}$ GROWTH $_{i t}+\alpha_{3}$ EISSUE $_{i t}+\alpha_{4} L E V_{i t}+$ $\alpha_{5} D_{S S S U E_{i t}}+\alpha_{6} T_{U R N_{i t}}+\alpha_{7} C F_{i t}+\alpha_{8} A U D_{i t}+\alpha_{9} N U M E X_{i t}+\alpha_{10} X I S T_{i t}+$ $\alpha_{11} C L O S E_{i t}+\sum_{k=1}^{k=2} \alpha_{k+12} S E C T_{i t}+\varepsilon_{i t}$

Since this is a linear regression, we therefore try to explain $\Delta \mathrm{NI}_{\mathrm{it}}$ or $\triangle \mathrm{CF}_{\text {it }}$ by a set of explanatory variables which are: SIZE, GROWTH, EISSUE, LEV, DISSUE, TURN, CF, AUD, NUMEX, XLIST, CLOSE, and SECT.

Thus, in this first model we focus on a particular practice of earnings management, which is the smoothing of results. Our measure is based on $(\Delta N I)$, which is the ratio of the variance of the change in net income to total assets.

Referring to Barth, Landsman and Lang's study, a variance of net results that converges to 0 is a sign that earnings management exists. It should be noted that for the sake of faithful representation we will take into account the residues $\left(\Delta N I^{*}\right)$. Indeed $\left(\Delta N I^{*}\right)$, gives a more real measure of earnings management [10].

Indeed, an increase of $\Delta N I_{i t}$ between the pre- and post-adoption period is interpreted as evidence of a decline in earnings management. An increase in $\Delta N I_{i t}$ implies that cash flows are more important than assets and therefore, as we have seen before, we can affirm that the entity has good governance resources. With reference to the accounting literature, we expect to find a decrease in earnings management for so-called "voluntary" companies from 2005 onwards.

To summarize, according to this first model we can measure the earnings of management either by $\Delta N I_{i t}$ it or by $\Delta C F$ in the case where we refer to $\triangle C F$ which is the relationship between the variance of the variability of the net results variability on the variance of the variability of the operating flows. This report is to be interpreted as follows: in the event that the company uses its accruals to manage its results, the variance in cash flow variability will be greater than that relating to net income.

$$
\begin{aligned}
& A_{C C} \text { orouCF }_{i t}=\alpha_{0}+\alpha_{1} \text { SIZE }_{i t}+\alpha_{2} \text { GROWTH }_{i t}+\alpha_{3} \text { EISSUE }_{i t}+\alpha_{4} L E V_{i t}+ \\
& \alpha_{5} \text { DISSUE }_{i t}+\alpha_{6} \text { TURN }_{i t}+\alpha_{7} C_{i t}+\alpha_{8} A U D_{i t}+\alpha_{9} N_{U M M E X_{i t}}+\alpha_{10} \text { XLIST }_{i t}
\end{aligned}
$$

In the above equation, the measurement of earnings management and more precisely the smoothing of results is based on the Spearman correlation. To measure the smoothing of the results, we will therefore compare the relationship of the residues between the accruals and the cash flows. The existence of a negative correlation means that when one of the variables increases cash flows, for example relative to the second variable decreases (increases) and vice versa, the existence of significant cash flows deters the practice of earnings management. The relationship between accruals and cash flow has been interpreted as follows: a negative correlation that has increased is evidence of the decline in earnings management practice, while a negative correlation that has decreased is evidence of an increase in earnings management.

Thanks to the estimates of equations 1 and 2, we will therefore measure all the parameters and those for our two panels.

\section{Timely loss recognition measures}

Equation 3 relates to the recognition of loss in good time or accounting conservatism which has been defined by Ettredge et al. as "a propensity to recognize losses more quickly than gains" [11].

$$
N I_{i t} / P_{t-1}=\beta_{0}+\beta_{1} R D_{i t}+\beta_{2} R_{i t}+\beta_{3} R_{i t} \times R D_{i t}+\varepsilon_{i}
$$

This equation comes from Basu's [4] model, named "Differential in the speed of publication in the results of bad news and good news".

In this model Basu uses the inverse regression based on the study of the relationship between the two components: the accounting result and the stock market return. 
Through this equation we can evaluate a company's ability to anticipate losses through coefficient $\beta_{3}$, a coefficient related to bad news. An increase in this coefficient is interpreted as proof that the company is able to anticipate possible losses more quickly, while a decrease in this coefficient reflects the company's failure to anticipate losses.

After a first estimation of the recognition of loss in a timely manner, we will present in equation 4 the model developed by Barth et al.

$N I_{i t} / T A_{t-1}=\delta_{0}+\delta_{1} N I D_{t-1}+\delta_{2} N I_{t-1} / T A_{t-2}+\delta_{3} N I D_{t-1} \times N I_{t-1} / T A_{t-2}+\varepsilon_{i}$

Indeed, according to Ball et al. if the $\delta_{3}$ coefficient remains largely negative after the adoption of IFRS, this result should be interpreted as a sign that the company is better able to anticipate its losses than before. On the other hand, if the coefficient $\delta_{3}$ increases this reflects the company's failure to anticipate losses.

\section{ANALYSIS OF EMPIRICAL RESULTS}

After presenting the selected sample, the models composed of the different variables selected, we will describe the statistics of the descriptive variables in the following Table 3:

\section{Descriptive statistics}

Reading the descriptive statistics relating to our two panels, we note (as do Christensen et al. [12]) that the average for the variables: growth, operating cash flow, size, number of stock exchanges on which a company's shares are listed, and listing on the US stock exchange was higher for companies that anticipated the adoption of IFRS.

\section{Results related to the earnings management of panel $\mathrm{A}$}

The Table 4 represents a comparison of the quality of accounting information for panel A before the voluntary adoption and after the adoption of IFRS.

Indeed, we observe that the variability of $\Delta N I$ increased after the

Table 3: Descriptive statistics of CAC companies.

\begin{tabular}{|c|c|c|c|c|c|c|c|c|c|}
\hline & \multicolumn{4}{|c|}{ Anticip (panel A) } & \multicolumn{5}{|c|}{ Non Anticip (panel B) } \\
\hline & $\mathrm{N}$ & $\bar{X}$ & $\mathrm{M}_{\mathrm{e}}$ & $\sigma$ & $\bar{X}$ & Sig. & $\mathrm{M}_{\mathrm{e}}$ & Sig. & $\sigma$ \\
\hline \multicolumn{10}{|l|}{ Test variables } \\
\hline$\Delta \mathrm{NI}$ & 36 & 0.0106 & 0.0061 & 0.0358 & 0.0218 & & 0.0078 & & 0.0457 \\
\hline$\Delta \mathrm{CF}$ & 36 & 0.0098 & 0.0075 & 0.0897 & -0.0009 & * & 0.0002 & * & 0.0919 \\
\hline $\mathrm{ACC}$ & 54 & 0.0002 & 0.0001 & 0.8147 & 0.0001 & & 0.005 & & 0.7894 \\
\hline $\mathrm{CF}$ & 54 & 0.0097 & 0.0025 & 0.0104 & 0.0068 & & 0.0018 & & 0.0145 \\
\hline SPOS & 54 & 0.2222 & 0 & 0.418 & 0.3333 & $* * *$ & 0 & * & 0.5148 \\
\hline $\mathrm{R}$ & 54 & 0.6025 & 0.1205 & 0.1781 & 0.1154 & * & 0.0187 & * & 0.1254 \\
\hline $\mathrm{NI} / \mathrm{P}$ & 54 & 0.0008 & 0.0001 & 0.0019 & 0.0003 & $* * *$ & 0 & * & 0.0001 \\
\hline$\Delta \mathrm{NI} / \mathrm{TA}$ & 36 & 0.0086 & 0.0031 & 0.0625 & 0.0099 & $* *$ & 0.0052 & * & 0.0452 \\
\hline $\mathrm{P}$ & 54 & 18.494 & 15.2 & 10.844 & 18.459 & & 15.322 & & 12.987 \\
\hline \multicolumn{10}{|c|}{ Control variables } \\
\hline LEV & & 4.5691 & 2.5649 & 6.2356 & 5.1234 & & 3.5698 & & 6.8791 \\
\hline GROWTH & 54 & 0.0945 & 0.0657 & 0.2547 & 0.0715 & * & 0.0365 & * & 0.3547 \\
\hline EISSUE & 54 & 0.6444 & 0.0024 & 0.8745 & 0.4521 & * & 0.0088 & * & 0.7456 \\
\hline DISSUE & 54 & 0.4518 & 0.0078 & 0.9874 & 0.3218 & * & 0.0091 & * & 0.4872 \\
\hline TURN & 54 & 1.5698 & 1.6547 & 2.4587 & 1.4571 & * & 1.8749 & * & 2.8792 \\
\hline SIZE & 54 & 9.0023 & 9.8974 & 3.4712 & 8.1279 & $* * *$ & 9.5784 & $* * *$ & 3.5687 \\
\hline $\mathrm{CF}$ & 54 & 0.0097 & 0.0025 & 0.0104 & 0.0068 & $* *$ & 0.0018 & $* *$ & 0.0145 \\
\hline NUMEX & 54 & 1.166 & 2.456 & 3.4712 & 0.9871 & $*$ & 1.2301 & * & 2.0145 \\
\hline XLIST & 54 & 0.1002 & 0.0001 & 0.4012 & 0.0999 & $* * *$ & 0.0002 & $* * *$ & 0.509 \\
\hline CLOSE & 54 & 0.4256 & 0.5214 & 0.7854 & 0.4789 & $* *$ & 0.572 & $* *$ & 0.5781 \\
\hline
\end{tabular}

Note: ${ }^{*}$ significance at the $10 \%$ level; ${ }^{* *}$ significance at the $5 \%$ level; ${ }^{* * *}$ significance at the $1 \%$ level.

Table 4: Estimation of earnings management for panel A.

\begin{tabular}{|c|c|c|c|c|c|c|c|c|}
\hline & Pre & Post & $\begin{array}{c}\text { Pré } \\
\text { adoption }\end{array}$ & $\begin{array}{c}\text { Post } \\
\text { adoption }\end{array}$ & $\begin{array}{l}\text { Expected } \\
\text { Sign }\end{array}$ & Difference & $\begin{array}{c}\% \text { de } \\
\text { difference }\end{array}$ & Sig. \\
\hline Variability of $\Delta \mathrm{NI}$ & 18 & 36 & 0.0091 & 0.015 & + & 0.0065 & $71.40 \%$ & $* *$ \\
\hline Variability of $\triangle C F$ & & & & & + & & & $* *$ \\
\hline \multirow[t]{2}{*}{ Variability of $\Delta N I / \Delta C F$} & 18 & 36 & 0.0095 & 6 & + & 0.0029 & $30.50 \%$ & $* *$ \\
\hline & 18 & 36 & 0.8712 & 0.0124 & + & 0.1411 & $16.10 \%$ & $* *$ \\
\hline \multirow[t]{2}{*}{ Variability of $\Delta N I^{*} / \Delta C F^{*}$} & & & & & + & & $37.08 \%$ & * \\
\hline & 18 & 36 & 0.9812 & 1.0123 & + & 0.3639 & & \\
\hline $\begin{array}{l}\text { Correlation } \\
\text { between } A C C \text { et } C F\end{array}$ & 18 & 36 & 0.0012 & 1.3451 & & -0.0011 & $-91.60 \%$ & \\
\hline $\begin{array}{l}\text { Correlation } \\
\text { between } A C C^{*} \text { et } C F^{*}\end{array}$ & 18 & 36 & 0.0011 & 0.0001 & & -0.0009 & $-81.81 \%$ & \\
\hline
\end{tabular}


adoption of IFRS for panel A. This variability went from 0.0091 to 0.0156 , an increase of about $71.4 \%$. This result therefore proves the effectiveness of IFRS on earnings management because an increase of $\Delta \mathrm{NI}$ implies a decrease in earnings management. Our results for our first earnings management measure for panel A are therefore in line with the study by Christensen et al., La pointe Antenus et al., Barth et al., Cormier and Martinez; but in contradiction with the study by Sefsaf and Capkun et al. [13] who found that the transition to IFRS has paradoxically led to an increase in results management $[5,10,12]$. These researchers explained these unexpected results by the fact that improving the quality of accounting information is not only dependent on the adoption of IFRS but also on the application of IFRS.

Concerning the variability ratio $\triangle \mathrm{NI} / \triangle \mathrm{CF}$ we also notice an increase of $\Delta \mathrm{NI} / \triangle \mathrm{CF}$ from 0.8712 before the anticipation to 1.0123 after (an increase of about 16\%). This second measure of earnings management shows a decrease in earnings management for companies in panel A.

With regard to the relationship between cash flows and accruals, the correlation is certainly positive, but it has declined following the early adoption of IFRS. Paradoxically, the more cash flow a company generates, the more the accruals tend to increase. This positive correlation decreased from 0.0012 to 0.0001 , a decrease of about $91.6 \%$. We can even say that there is almost no relationship between these two variables for our panel A. Our results concerning the relationship between accruals and cash flows are not in line with the results of Christensen et al. and Sefsaf, in particular the absence of a relationship may be due to the small sample size $[12,13]$.

The explanation we could give is that for our panel A there is no relationship between accruals and cash flow. The increase or decrease in accruals is independent of cash flow, but may depend on other factors such as financial distress and the quality of governance.

Thus, we can affirm that the empirical analysis validated our first hypothesis.

\section{Results related to the recognition of the timely loss of panel A}

By analysing equation 3 we find that the coefficient $\beta_{3}$ incorporating bad news increased by about $66.61 \%$ for companies in panel A. This coefficient rose from 0.1875 to 0.3124 . This increase in the coefficient on the disclosure of bad news proves a better anticipation of losses. We can therefore affirm that according to this equation, which is derived from Basu's model, panel A companies anticipate losses better after the early adoption of IFRS than before the anticipation [4].

In other words, these economic entities better incorporate probable losses into their forecast documents (Table 5).

As for the second measure of timely loss recognition, according to Ball et al. in the case where $\delta_{3}$ is largely negative this means that economic entities are more able to anticipate losses than before [7]. Thus, referring to equation 4 this coefficient is largely negative, it has gone from -0.2689 to -0.2978 . By reviewing the empirical studies on the subject of conservatism, we can therefore affirm that the results from equations 3 and 4 are in line with the results of Christensen, Lee and Walker [12] where these authors concluded after analysis that German companies qualified as "voluntary adopters" predicted probable losses more quickly than German companies qualified as "resisters adopters" who decided not to anticipate the adoption of IFRS.

\section{Results related to the measurement of earnings management for panel B}

Indeed, for the first attribute of the quality of accounting information relating to earnings management, we observe that the variability of $\Delta N I$ has decreased. This decrease of $\Delta N I$ means that there was an increase in earnings management after the mandatory adoption of IFRS or after 2005. Our first measure of earnings management is consistent with the result found by Christensen et al. for the first measure of earnings management for so-called "resistant" companies. The company's failure to anticipate the adoption of IFRS has delayed its ability to disclose quality information (Table 6).

From the results found, we can conclude that there has been an increase in earnings management for panel B after 2005. This increase in earnings management is in line with the statement of Daske,Verdi, Hail, Leuz that there are two types of adopters: those who adopt IFRS in the belief that they are quality standards adapted to the requirements of the new environment and therefore

Table 5: Estimating the recognition of loss in a timely manner for the panel A.

\begin{tabular}{|c|c|c|c|c|c|c|}
\hline \multicolumn{7}{|c|}{$N I_{i t} / \mathrm{P}_{t-1}=\beta_{0}+\beta_{1} R D_{i t}+\beta_{2} R_{i t}+\beta_{3} R_{i t} \times R D_{i t}+\varepsilon_{i}$} \\
\hline & $\beta_{2}$ & $\mathrm{t}\left(\beta_{2}\right)$ & $\beta_{3}$ & $t\left(\delta_{a}\right)$ & $R^{2}$ adjus. & $\mathrm{N}$ \\
\hline Pre adoption & 0.0001 & 0.0005 & 0.1875 & 6.54 & $30.12 \%$ & 36 \\
\hline Post adoption & 0.0258 & 0.13 & 0.3124 & 1.56 & $25.71 \%$ & 36 \\
\hline Expected Sign & $+/-$ & $+/-$ & & & & \\
\hline $\begin{array}{l}\text { Te pre- and post-adoption testing } \\
\text { difference }\end{array}$ & 0.0257 & & 0.1249 & & $20.54 \%$ & 72 \\
\hline Sig. & No & & $*$ & & & \\
\hline \multicolumn{7}{|c|}{$N I_{i t} / \mathrm{TA}_{t-1}=\delta_{0}+\delta_{1} N I D_{t-1}+\delta_{2} N I_{t-1} / T A_{t-2}+\delta_{3} N I D_{t-1} \times N I_{t-1} / T A_{t-2}+\varepsilon_{i}$} \\
\hline & $\delta_{2}$ & $\mathrm{t}\left(\delta_{2}\right)$ & $\delta_{3}$ & $\mathrm{t}\left(\delta_{3}\right)$ & $R^{2}$ ajus. & $\mathrm{N}$ \\
\hline Sig. Pre adoption & 0.0351 & 0.56 & -0.2689 & -4.3 & $20.92 \%$ & 18 \\
\hline Post adoption & 0.1548 & 2.97 & -0.2978 & -5.72 & $12.68 \%$ & 36 \\
\hline Expected Sign & $+/-$ & & & & & \\
\hline \multirow{2}{*}{$\begin{array}{l}\text { Te pre- and post-adoption testing } \\
\text { difference }\end{array}$} & 0.1197 & & -0.0289 & & $13.49 \%$ & 54 \\
\hline & No & & * & & & \\
\hline
\end{tabular}

Note: * significance at the $10 \%$ level. 
Table 6: Estimate of earnings management for panel B.

\begin{tabular}{|c|c|c|c|c|c|c|c|}
\hline & Pre & Post & Pré adoption & Post adoption & Expected Sign & Difference & $\%$ de difference \\
\hline Variability of $\Delta \mathrm{NI}$ & 18 & 36 & 0.0147 & 0.0117 & + & 0.0065 & $71.40 \%$ \\
\hline Variability of $\Delta \mathrm{NI}^{*}$ & 18 & 36 & 0.0195 & 0.0111 & + & 0.0029 & $30.50 \%$ \\
\hline Variability of $\Delta N I / \Delta C F$ & 18 & 36 & 0.8812 & 0.6879 & + & 0.1411 & $16.10 \%$ \\
\hline Variability of $\Delta \mathrm{NI}^{*} / \Delta C F^{*}$ & 18 & 36 & 0.9958 & 1.2589 & + & & $37.08 \%$ \\
\hline Correlation between $A C C$ and $C F$ & 18 & 36 & 0.0022 & 0.0003 & + & 0.3639 & $-91.60 \%$ \\
\hline Correlation between $A C C^{*}$ and $C F^{*}$ & 18 & 36 & 0.0071 & 0.0062 & + & -0.0011 & $-81.81 \%$ \\
\hline
\end{tabular}

apply IFRS in a rigorous way-they are "serious adopters". Those who adopt IFRS without being convinced of the positive impact of IFRS on the quality of accounting information according to these adopters IFRS are simply reduced to standards that are imposed by the regulatory framework are the "label adopters". We can therefore assimilate our panel B to this second type of adopters, the "label adopters".

The "label adopters" consider IFRS as a kind of quality label and therefore do not make efforts such as setting up effective governance mechanisms to ensure the success of IFRS. They believe that simply adopting is enough to say that accounts are quality accounts. This first result on the impact of IFRS on earnings management is consistent with the results of the study by Barth, Landsman and Lang, Paglietti and Calloa in that they stated that "IFRS offered a range of accounting options that paved the way for the practice of earnings management, resulting in an increase in earnings management after the adoption of IFRS".

Concerning the correlation between accruals and cash flows, we note that this correlation is positive, but it has decreased between the pre-adoption and post-adoption phases. Our results concerning the correlation between accruals and cash flows are not in line with the results of Christensen, Lee Walker where these authors found after statistical analysis the existence of negative correlation for both "voluntary adopters" and "serious adopters". Thus, in the German context the more cash flows increase, the more accruals decrease, which is expected. The more profitable a company is, the more it does not need to manage its results.

\section{Results of timely loss recognition measurements}

By analyzing equation 3 we notice that the coefficient $\beta_{3}$, which takes into account bad news, decreased instead of increasing. This result proves that the adoption of IFRS has not enabled the economic entities in panel B to better anticipate losses. We can therefore say that for these companies, there has been a drop in the level of conservatism because these companies recognize good news more than bad news. This result is therefore consistent with the study by Christensen et al. where the authors found that business entities that have decided not to opt for early adoption of IFRS, so-called "resistant" companies, have a $\beta_{3}$ coefficient (bad news coefficient) that declined significantly after the mandatory adoption of IFRS. Indeed it went from 0.3061 to 0.0320 , a decrease of about $89.54 \%$. This result is in line with the study by Ding and Stowly where the authors found that in the French context the adoption of IFRS led to a marked decrease in the level of conservatism (Table 7).

However, our result is in contradiction with Garcia Lara ,Rueda Torres and Vasquez Veira's study where the authors concluded that there was an increase in conservatism following the adoption of IFRS (they noted that more efforts are being made to recognize probable losses).
Table 7: Estimate of timely loss recognition for panel B.

\begin{tabular}{|c|c|c|c|c|c|c|}
\hline \multicolumn{7}{|c|}{$N I_{i t} / \mathrm{P}_{t-1}=\beta_{0}+\beta_{1} R D_{i t}+\beta_{2} R_{i t}+\beta_{3} R_{i t} \times R D_{i t}+\varepsilon_{i}$} \\
\hline & $\beta_{2}$ & $\mathrm{t}\left(\beta_{2}\right)$ & $\beta_{3}$ & $t(\delta)$ & $\begin{array}{c}R^{2} \\
\text { adjus. }\end{array}$ & $\mathrm{N}$ \\
\hline Pre adoption & -0.0001 & -0.04 & 0.2235 & 7.56 & $10.11 \%$ & 36 \\
\hline Post adoption & 0.0258 & 0.22 & 0.1987 & 0.55 & $7.71 \%$ & 36 \\
\hline \multicolumn{7}{|l|}{ ExpectedSign } \\
\hline $\begin{array}{l}\text { Te pre- and } \\
\text { post-adoption } \\
\text { testingdifference }\end{array}$ & & & & & $8.11 \%$ & 72 \\
\hline Sig. & No & & * & & & \\
\hline \multicolumn{7}{|c|}{$N I_{i t} / \mathrm{TA}_{t-1}=\delta_{0}+\delta_{1} N I D_{t-1}+\delta_{2} N I_{t-1} / T A_{t-2}+\delta_{3} N I D_{t-1} \times N I_{t-1} / T A_{t-2}+\varepsilon_{i}$} \\
\hline & & $\delta_{2}$ & $\mathrm{t}\left(\delta_{2}\right)$ & $\delta_{3}$ & $\mathrm{t}\left(\delta_{3}\right)$ & $R^{2}$ adjus. \\
\hline Pre adoption & & 0.0352 & 0.62 & -0.3679 & -5.44 & $12.92 \%$ \\
\hline Post adoption & & 0.1505 & 2.99 & -0.5861 & -8.32 & $5.68 \%$ \\
\hline \multicolumn{7}{|l|}{ ExpectedSign } \\
\hline $\begin{array}{l}\text { Pre- and post-adop } \\
\text { testing difference }\end{array}$ & & & & & & $6.77 \%$ \\
\hline Sig. & & No & & * & & \\
\hline
\end{tabular}

Note: * significance at the $10 \%$ level.

Referring to equation 4 we notice that even for panel B, coefficient $\delta_{3}$, as in panel $\mathrm{A}$, is largely negative. It fell from -0.3679 to -0.5861 , a decrease of about $59 \%$; so this coefficient is largely negative. We can therefore affirm that the companies in panel $\mathrm{B}$ anticipate more likely losses after the mandatory adoption of IFRS.

The different estimates on panel B highlighted the following points: an increase in earnings management and an anticipation of losses that depends on the methodology used. In other words, if we refer to equation 3, companies do not anticipate losses better after the adoption of IFRS, but if we refer to equation 4, companies ensure better loss anticipation.

After having formulated our research problem and stated our assumptions regarding the various attributes of the accounting information, we have validated our assumptions for the companies in panel A using the various estimates. The early adoption of IFRS in 2004 enabled these economic entities to present accounting information that was less subject to earnings management. A total disappearance of earnings management is impossible to achieve given the opportunistic behaviour of the leader who will use all manipulations and techniques to display a result that primarily serves his personal interests. The accounting information presented by these economic entities makes it possible to better anticipate probable losses than the companies in panel B. Thus, in the light of the results we have obtained, we can affirm that the added value of this research is to show companies that the transition to IFRS will give them significant advantages: quality accounting information will strengthen investors confidence in the purchase of the company's shares and therefore ensure the 
continuity of the company's transactions. The fact that a company continues to operate makes it possible to ensure financial stability for employees.

Since the concept of quality is a multidimensional concept, we have chosen to analyze the following attributes: earnings management and timely recognition of loss for our two panels: panel A and panel B. The purpose of this article was to present the contributions of early adoption of IFRS for French CAC 40 companies.

After empirical analysis, we confirmed in the French context our assumptions regarding the beneficial contribution of IFRS on the quality of accounting information. Our answer is unequivocal, the early adoption of IFRS is a guarantee of better quality accounting information. At the end of our research we proved that the companies in panel A had a smaller earnings management and a better recognition of losses in a timely manner.

For panel B companies, we have shown that the mandatory adoption of IFRS did not have the same effect for these companies because earnings management did not decrease in 2006, which can be explained by the fact that the adoption of IFRS requires some preparation, both tangible and intangible. The company must have funds to ensure the transition from local to international standards, including competent personnel who can apply these international accounting standards with care and rigour. Not anticipating the adoption of IFRS "handicapped" in a way the companies in panel B.

Thus, the contributions of this research are both theoretical and empirical. To our knowledge, our study is the first study to examine the impact of the early adoption of IFRS on the quality of accounting information in the French context, and thus contributes to enriching the accounting literature. The results we have achieved could encourage companies to adopt IFRS.

On the managerial level, our research is helping to raise awareness among companies that have not yet adopted IFRS to opt for these standards in order to provide investors with high-quality accounting information that is impermeable to future financial scandals. Thus, our research provides added value to companies by providing them with evidence of the salutary contributions of IFRS on the quality of accounting information.

Nevertheless, as with any research work, some limitations were noted, such as the small sample size, which made it difficult to generalize the results, a relatively short study period and the fact that our study focused on a single EU member country, which made it difficult to generalize these results to all EU member countries [14-16].

\section{CONCLUSION}

Thus, in view of the different limitations encountered, future research could study the following themes:

-Study the influence of the cultural factor in deciding whether or not to anticipate the adoption of IFRS.
-Carry out a study on the impact of the early adoption of IFRS on the quality of accounting information of economic entities in developing countries.

\section{REFERENCES}

1. Kim J, Zhang L. Financial reporting opacity and expected crash risk: Evidence from implied volatility smirks. Contemporary Accounting Research. 2013;31:851-875.

2. Colasse B. The paths of research in financial accounting: Teachings and research in management, evolution and perspectives, Press of the University of Social Sciences of Toulouse. 1995;297-307.

3. Hoarau C. Should France have an accounting conceptual framework? French Accounting Review. 1992;58-62.

4. Basu S. The Conservatism Principle and the Asymmetric Timeliness of Earnings. J Account Econ. 1997;24:3-37

5. Capkun V, Jeny A, Jeanjean T, Weiss LA. Earnings Management and Value Relevance during the Mandatory Transition from Local GAAPS to IFRS in Europe. 2008.

6. Ahmed K, Chalmers K, Khlif H. A meta-analysis of IFRS adoption effects. The International Journal of Accounting. 2013;48:173-217.

7. Ball R, Robin A, Wu JS. incentives versus Standards: Properties of Accounting in Four East Asian Countries. J Account Econ. 2003; $36: 235-270$

8. André P, Filip A. Accounting Conservatism in Europe and the Impact of Madatory IFRS Adoption: A Look at Legal lncentives, Corporate Govemance, Enforceemnt Prior Accounting Traditions and Tax Book Conformity. Financial Reporting ESSEC-KPMG Center. 2011;50.

9. Masca E, Neag R. Accounting conservatism in Europe: a literature revie, Procedings of the 2 nd International Scientific Conference IFRS: Global Rules\& Local Use, Anglo-American University, Prague, Czech Republic. 2014;113-127.

10. Barth M, Landsman WR, Lang R. International accounting standards and accounting quality. J Account Res. 2008;46:467-498.

11. Ettredgen ML, Huang Y, Weining Z. Conservative reporting and securities class action lawsuits. Accounting Horizons. 2016;30:93-118.

12. Christensen. Incentives or standards, what determines accounting quality change around IFRS adoption? European Accounting Review. 2015;24:31-61.

13. Reda Sefsaf. Contribution to the analysis of the effect of the adoption of IFRS on the quality of accounting figures. Granem - Groupe de Recherche ANgevin en Economie et Management. 2014.

14. Dimitropoulos PE, Asteriou D, Kousenidis D, Leventis S. The impact of IFRS on accounting quality: Evidence from Greece. Advances in Accounting. 2013;29:108-123.

15. Khan M, Watts RL. Estimation and Empirical properties of a FirmYear Measure of Accounting Conservatism. J Accounting Econ. 2009; 48:132-150.

16. Razzaq N, Ashfaq k, Rui Z, Donghua Z. Does Conservatism Alleviates Firms from Under-over Investments in Pakistan? Research Journal of Finance and Accounting. 2016;7. 